\title{
DNA Interactions of Monofunctional Organometallic Ruthenium(II) Antitumor Complexes in Cell-free Media ${ }^{\dagger}$
}

\author{
Olga Novakova, ${ }^{\ddagger}$ Haimei Chen, ${ }^{\S}$ Oldrich Vrana, ${ }^{\ddagger}$ Alison Rodger," Peter J. Sadler, ${ }^{*}, \S$ and Viktor Brabec $*, \ddagger$ \\ Institute of Biophysics, Academy of Sciences of the Czech Republic, Kralovopolska 135, CZ-61265 Brno, Czech Republic, \\ School of Chemistry, University of Edinburgh, West Mains Road, Edinburgh EH9 3JJ, United Kingdom, and \\ Department of Chemistry, University of Warwick, Coventry CV4 7AL, United Kingdom
}

Received May 30, 2003; Revised Manuscript Received August 5, 2003

\begin{abstract}
Modifications of natural DNA in a cell-free medium by antitumor monodentate Ru(II) arene compounds of the general formula $\left[\left(\eta^{6} \text {-arene }\right) \mathrm{Ru}(\mathrm{en}) \mathrm{Cl}\right]^{+}$(arene $=$biphenyl, dihydroanthracene, tetrahydroanthracene, $p$-cymene, or benzene; en = ethylenediamine) were studied by atomic absorption, melting behavior, transcription mapping, circular and linear dichroism, plasmid unwinding, competitive ethidium displacement, and differential pulse polarography. The results indicate that these complexes bind preferentially to guanine residues in double-helical DNA. The data are consistent with DNA binding of the complexes containing biphenyl, dihydroanthracene, or tetrahydroanthracene ligands that involves combined coordination to G N7 and noncovalent, hydrophobic interactions between the arene ligand and DNA, which may include arene intercalation and minor groove binding. In contrast, the single hydrocarbon rings in the $p$-cymene and benzene ruthenium complexes cannot interact with double-helical DNA by intercalation. Interestingly, the adducts of the complex containing $p$-cymene ligand, which has methyl and isopropyl substituents, distort the conformation and thermally destabilize double-helical DNA distinctly more than the adducts of the three multiring ruthenium arene compounds. It has been suggested that the different character of conformational alterations induced in DNA, and the resulting thermal destabilization, may affect differently further "downstream" effects of damaged DNA and consequently may result in different biological effects of this new class of metal-based antitumor compounds. The results point to a unique profile of DNA binding for $\mathrm{Ru}$ (II) arene compounds, suggesting that a search for new anticancer compounds based on this class of complexes may also lead to an altered profile of biological activity in comparison with that of metal-based antitumor drugs already used in the clinic or currently on clinical trials.
\end{abstract}

Platinum coordination compounds are widely used as antitumor drugs. The first platinum antitumor drugs introduced in the clinic were cis-diamminedichloroplatinum(II) ${ }^{1}$ (cisplatin) and its somewhat less toxic analogue carboplatin [cis-diammine-1,1-cyclobutanedicarboxylatoplatinum(II)]. Both compounds show the same spectrum of antitumor activity. The clinical efficacy of these anticancer drugs is diminished by intrinsic and acquired tumor resistance. Owing to these limitations, there is an intense effort to design new transitionmetal-based compounds that are capable of overcoming problems associated with cisplatin and carboplatin chemotherapy while delivering the therapeutic effect.

† Supported by the Grant Agency of the Czech Republic (Grant Nos. 305/02/1552, 305/01/0418), the Grant Agency of the Academy of Sciences of the Czech Republic (Grant No. A5004101), The Wellcome Trust (U.K.), the Committee of Vice-Chancellors and Vice-Principals (Overseas Research Scholarship to HC), and the Edinburgh Technology Fund. The authors acknowledge that this research is also a part of the European Cooperation in the field of Scientific and Technical Research network (COST projects D20/0003/00 and D20/0005/01).

* Corresponding authors. VB: telephone, 420-541517148; fax, 420541240499; e-mail, brabec@ibp.cz. PJS: telephone, +44-131-6504729; fax, +44-131-6506452; e-mail, P.J.Sadler@ed.ac.uk.

Institute of Biophysics, Academy of Sciences of the Czech Republic.

$\S$ School of Chemistry, University of Edinburgh.

"Department of Chemistry, University of Warwick.
Cisplatin and carboplatin target cellular DNA, forming covalent adducts (1). The most abundant adducts formed by cisplatin in linear DNA are $1,2-\mathrm{d}(\mathrm{GpG})(\sim 65 \%)$ or $1,2-$ $\mathrm{d}(\mathrm{ApG})(25 \%)$ intrastrand and 1,2-d(GG) $(\sim 6 \%)$ interstrand cross-links $(2-4)$. In the years following the introduction of cisplatin, the design of new platinum antitumor drugs concentrated mainly on direct cisplatin analogues which adhered to the set of structure-activity relationships established as early as $1973(5,6)$. More recently, there have been efforts to design rationally unconventional platinum complexes that violate these original structure-activity relationships, such as polynuclear platinum complexes or analogues of the clinically ineffective trans isomer of cisplatin (transplatin) (7-9). There have also been efforts directed at the

\footnotetext{
${ }^{1}$ Abbreviations: BEN, benzene; BIP, biphenyl; $\mathrm{CD}$, circular dichroism; cisplatin, cis-diamminedichloroplatinum(II); CT, calf thymus; CYM, p-cymene; DHA, dihydroanthracene; DPP, differential pulse polarography; en, ethylenediamine; EtBr, ethidium bromide; FAAS, flameless atomic absorption spectrophotometry; LD, linear dichroism; $[\mathrm{Pt}($ dien $) \mathrm{Cl}] \mathrm{Cl}$, chlorodiethylenetriamineplatinum(II) chloride; dien = diethylenetriamine; poly $(\mathrm{dG}-\mathrm{dC})$, polymer of alternating $\mathrm{dG}$ and $\mathrm{dC}$ residues; poly(dA-dT), polymer of alternating dA and dT residues; $r_{\mathrm{b}}$, the number of metal atoms bound per nucleotide residue; $r_{\mathrm{i}}$, the molar ratio of free metal complex to nucleotide-phosphates at the onset of incubation with DNA.; THA, tetrahydroanthracene; $t_{\mathrm{m}}$, DNA melting temperature; transplatin, trans-diamminedichloroplatinum(II).
} 
design of other transition-metal antitumor agents. Possible advantages in using transition-metal ions other than $\mathrm{Pt}(\mathrm{II})$ include the availability of additional coordination sites in octahedral complexes and the altered shape of the complex, alterations in ligand affinity and substitution kinetics, changes in oxidation state, and photodynamic approaches to therapy. In the design of these new drugs, ruthenium complexes have attracted much interest $(10-12)$.

Organometallic ruthenium(II) arene complexes of the type [( $\eta^{6}$-arene $\left.) \mathrm{Ru}(\mathrm{II})(\mathrm{en}) \mathrm{Cl}\right]\left[\mathrm{PF}_{6}\right]$ (en = ethylenediamine) constitute a relatively new group of anticancer compounds ( 13 , 14). These are pseudo-octahedral "piano-stool" complexes with the arene ring occupying three coordination sites and two diamine nitrogens and the halide ligand occupying the remaining three sites. Importantly, the arene ligand is strongly bound and stabilizes ruthenium(II): the complexes do not readily undergo oxidation to ruthenium(III). Moreover, most of the compounds are ionic and have a reasonable aqueous solubility. These monodentate $\mathrm{Ru}(\mathrm{II})$ arene complexes have been considered novel anticancer agents with a mechanism of action different from that of the ruthenium(III) complex $(\mathrm{ImH})\left[\right.$ trans $\left.-\mathrm{Ru}(\mathrm{III}) \mathrm{Cl}_{4} \mathrm{Im}\left(\mathrm{Me}_{2} \mathrm{SO}\right)\right]\{\mathrm{Im}=$ imidazole, NAMIA\}, which is currently on clinical trial $(11,15)$.

Broadening the chemotherapeutic arsenal depends on understanding existing agents with a view toward developing new modes of attack. Interestingly, a direct correlation between cytotoxicity and DNA binding has already been observed for several ruthenium compounds in cell cultures (16). Also consistent with DNA binding in vivo, a number of ruthenium compounds inhibit DNA replication, exhibit mutagenic activity, induce the SOS repair mechanism, bind to nuclear DNA, and reduce RNA synthesis (16). Similarly, several antitumor ruthenium compounds have also been shown (17-21) to bind to DNA and inhibit DNA replication in vitro, but the pharmacological target for ruthenium compounds and the mechanism underlying its biological effects are not known.

The $\left(\eta^{6}\right.$-arene) $\mathrm{Ru}(\mathrm{II})$ bonds are inert toward hydrolysis, but the monofunctional complexes $\left[\left(\eta^{6} \text {-arene) } \mathrm{Ru}(\mathrm{II})(\mathrm{en})(\mathrm{Cl})\right]^{+}\right.$ readily lose their chloride ligand and transform into the corresponding, more reactive, aquated species (22). It has also been shown (14) that the complex [ $\left(\eta^{6}-p\right.$-cymene $) \mathrm{Ru}-$ (II)(en) $(\mathrm{Cl})]^{+}$binds to a short, single-stranded deoxyribooligonucleotide (14-mer), forming monofunctional adducts, and that the preferential sites of ruthenation in this oligomer are guanine residues. To address further fundamental questions about DNA binding modes of ruthenium(II) arene antitumor compounds, the experiments described in the present paper were carried out. More specifically, the interactions of polymeric B-DNAs with $\left[\left(\eta^{6}\right.\right.$-arene $) \mathrm{Ru}(\mathrm{II})(\mathrm{en})$ $(\mathrm{Cl})]^{+}$complexes $[$where arene $=$biphenyl $(\mathrm{BIP})$, dihydroanthracene (DHA), tetrahydroanthracene (THA), p-cymene (CYM), or benzene (BEN)] in cell-free media were investigated by various biochemical and biophysical methods with the goal to contribute to understanding their biological effects and to help establish structure-pharmacological relationships for this class of ruthenium anticancer compounds.

\section{MATERIALS AND METHODS}

Starting Materials. $\left[\left(\eta^{6}\right.\right.$-arene $\left.) \mathrm{Ru}(\mathrm{II})(\mathrm{en})(\mathrm{Cl})\right] \mathrm{PF}_{6}$ complexes (Figure 1) were prepared as described previously (23).

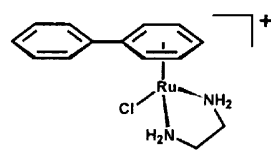

Ru-BIP

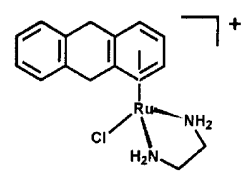

Ru-DHA

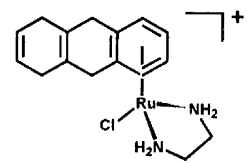

Ru-THA

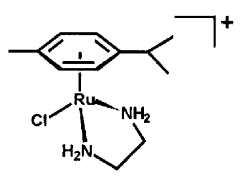

Ru-CYM

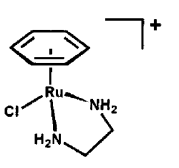

Ru-BEN
FIGURE 1: Structures of $\mathrm{Ru}(\mathrm{II})$ arene complexes used in this work.

Cisplatin, trans-diamminedichloroplatinum(II) (transplatin), and chlorodiethylenetriamineplatinum(II) chloride $\{[\mathrm{Pt}(\mathrm{dien})$ $\mathrm{Cl}] \mathrm{Cl}\}$ were synthesized and characterized at Lachema (Brno, Czech Republic). The stock solutions of the ruthenium and platinum complexes $\left(5 \times 10^{-4} \mathrm{M}\right.$ in $\left.\mathrm{H}_{2} \mathrm{O}\right)$ were prepared in the dark at $25^{\circ} \mathrm{C}$ and stored for at least 7 days before they were used. Aquation of these $\mathrm{Ru}(\mathrm{II})$ arene complexes is relatively rapid in water (22), and as for cisplatin, the aqua adducts are more reactive than the chloro complexes. Calf thymus (CT) DNA ( $42 \% \mathrm{G}+\mathrm{C}$, mean molecular mass $\sim 2$ $\times 10^{7}$ ) was also prepared and characterized as described previously $(24,25)$. Poly $(\mathrm{dG}-\mathrm{dC})$ and poly $(\mathrm{dA}-\mathrm{dT})$ were obtained from Amersham Pharmacia-Biotech (Piscataway, $\mathrm{NJ})$ and were used without further purification.

Plasmid pSP73KB [2455 bp (26)] was isolated according to standard procedures and banded twice in $\mathrm{CsCl} / \mathrm{EtBr}$ equilibrium density gradients. Restriction endonucleases were purchased from New England Biolabs (Beverly, MA). Riboprobe Gemini System II for transcription mapping containing SP6 and T7 RNA polymerases was purchased from Promega (Madison, WI). Ethidium bromide (EtBr) and agarose were from Merck KgaA (Darmstadt, Germany). The radioactive products were from Amersham (Arlington Heights, IL).

Metalation Reactions. CT DNA and plasmid DNAs were incubated with ruthenium or platinum complex in $10 \mathrm{mM}$ $\mathrm{NaClO}_{4}(\mathrm{pH} \sim 6)$ at $37{ }^{\circ} \mathrm{C}$ for $48 \mathrm{~h}$ in the dark, if not stated otherwise. The number of atoms of the metal bound per nucleotide residue ( $r_{\mathrm{b}}$ values) was determined by flameless atomic absorption spectrophotometry (FAAS) (21).

DNA Transcription by RNA Polymerase in Vitro. Transcription of the (NdeI/HpaI) restriction fragment of pSP73KB DNA with SP6 or T7 RNA polymerase and electrophoretic analysis of transcripts were performed according to the protocols recommended by Promega (Promega Protocols and Applications, 43-46 (1989/90)) and previously described in detail $(26,27)$.

Unwinding of Negatively Supercoiled DNA. Unwinding of closed circular supercoiled pSP73KB plasmid DNA was assayed by an agarose gel mobility shift assay (28). The unwinding angle, $\Phi$, induced per metal-DNA adduct was calculated upon the determination of the $r_{\mathrm{b}}$ value at which the complete transformation of the supercoiled form to the relaxed form of the plasmid was attained. Samples of pSP73 plasmid were incubated with $\mathrm{Ru}(\mathrm{II})$ arene or cisplatin in 10 $\mathrm{mM} \mathrm{NaClO} 4$ at $37^{\circ} \mathrm{C}$ in the dark for $48 \mathrm{~h}$. All samples were precipitated by ethanol and redissolved in TAE buffer $(0.04$ 
M Tris-acetate +1 mM EDTA, $\mathrm{pH}$ 7.0). An aliquot of the precipitated sample was subjected to electrophoresis on $1 \%$ agarose gels running at $25{ }^{\circ} \mathrm{C}$ in the dark with TAE buffer with a voltage set at $30 \mathrm{~V}$. The gels were then stained with $\mathrm{EtBr}$, followed by photography on Polaroid 667 film with transilluminator. The other aliquot was used for the determination of $r_{\mathrm{b}}$ values by FAAS.

Circular Dichroism (CD) and Linear Dichroism (LD). If not stated otherwise, $C D$ and LD spectra of DNA modified by the ruthenium complexes were recorded at $25^{\circ} \mathrm{C}$ in 10 $\mathrm{mM} \mathrm{NaClO}{ }_{4}$ on JASCO J-720 and adapted J-715 spectropolarimeters.

Differential Pulse Polarography. Differential pulse polarographic (DPP) curves of DNA were measured after nonmodified DNA or DNA modified by either Ru(II) arene compound used in the present work was redissolved in a medium consisting of $0.3 \mathrm{M}$ ammonium formate plus 0.05 $\mathrm{M}$ phosphate $\left(\mathrm{Na}_{2} \mathrm{HPO}_{4} / \mathrm{NaH}_{2} \mathrm{PO}_{4}\right)$ buffer, pH 6.8. DPP curves were recorded with the aid of an EG\&C PARC electrochemical analyzer, model $384 \mathrm{~B}$ at $25{ }^{\circ} \mathrm{C}$ using the following apparatus settings: voltage scan rate of $2 \mathrm{mV} / \mathrm{s}$, pulse amplitude of $5 \mathrm{mV}$, drop time of $1.0 \mathrm{~s}$. The potentials are relative to the saturated calomel reference electrode (SCE).

Fluorescence Measurements. Fluorescence measurements in the presence of EtBr of CT DNA modified by ruthenium arene complexes were performed at an excitation wavelength of $546 \mathrm{~nm}$, and the emitted fluorescence was analyzed at $590 \mathrm{~nm}$. The fluorescence intensity was measured at $25^{\circ} \mathrm{C}$ in $0.4 \mathrm{M} \mathrm{NaCl}$ to avoid secondary binding of EtBr to DNA $(29,30)$. The concentrations were $0.01 \mathrm{mg} / \mathrm{mL}$ for DNA and $0.04 \mathrm{mg} / \mathrm{mL}$ for $\mathrm{EtBr}$, which corresponded to the saturation of all intercalation sites of EtBr in DNA $(29,30)$. These measurements were performed on a Shimadzu RF 40 spectrofluorophotometer using a $1 \mathrm{~cm}$ quartz cell.

DNA Melting. The melting curves of DNA were recorded by measuring the absorbance at $260 \mathrm{~nm}$. The melting curves of unruthenated or ruthenated DNA were recorded after Tris$\mathrm{HCl} / \mathrm{EDTA}$ buffer and $\mathrm{NaClO}_{4}$ were added so that the resulting media contained $0.01-0.2 \mathrm{M} \mathrm{NaClO}_{4}$ with $1 \mathrm{mM}$ Tris- $\mathrm{HCl} / 0.1 \mathrm{mM}$ EDTA, $\mathrm{pH}$ 7.4. The value of the melting temperature $\left(t_{\mathrm{m}}\right)$ was determined as the temperature corresponding to a maximum on the first-derivative profile of the melting curves. The $t_{\mathrm{m}}$ values were thus determined with an accuracy of $\pm 0.3{ }^{\circ} \mathrm{C}$.

Other Methods. Absorption spectra were measured with Beckmann DU-7400 and Cary 1E spectrophotometers. FAAS measurements were carried out on a Unicam 939 AA spectrometer with a graphite furnace. For FAAS analysis, DNA was precipitated with ethanol and dissolved in $0.1 \mathrm{M}$ $\mathrm{HCl}$.

\section{RESULTS}

DNA Binding. Solutions of double-helical CT DNA at a concentration of $0.1 \mathrm{mg} / \mathrm{mL}$ were incubated with $\mathrm{Ru}(\mathrm{II})$ arene complexes at an $r_{\mathrm{i}}$ (molar ratio of free ruthenium complex to nucleotide phosphates at the onset of incubation with DNA) value of 0.1 in $10 \mathrm{mM} \mathrm{NaClO} 4$ at $37{ }^{\circ} \mathrm{C}$. At various time intervals, an aliquot of the reaction mixture was withdrawn, quickly cooled on an ice bath, and precipitated by ethanol, and the content of ruthenium in the supernatant

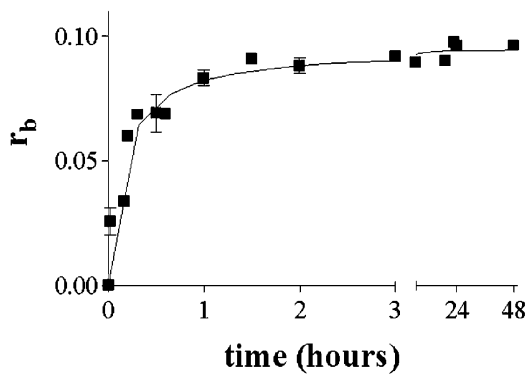

FIGURE 2: Kinetics of the binding of the $\mathrm{Ru}(\mathrm{II})$ arene compound $\mathrm{Ru}-\mathrm{BIP}$ to calf thymus DNA. Medium: $10 \mathrm{mM} \mathrm{NaClO}_{4}$ at 37 ${ }^{\circ} \mathrm{C}$. The concentration of DNA was $0.1 \mathrm{mg} / \mathrm{mL} ; r_{\mathrm{i}}=0.1$. Data measured in triplicate varied on average $\pm 3 \%$ from their mean.

of these samples was determined by FAAS. Figure 2 shows a plot of $r_{\mathrm{b}}$ (the number of atoms of metal bound per nucleotide residue) against the time of DNA incubation with $\mathrm{Ru}-\mathrm{BIP}\left(r_{\mathrm{i}}=0.1\right)$. The amount of ruthenium bound per DNA nucleotide phosphate $\left(r_{\mathrm{b}}\right)$ increased with time. After $\sim 3 \mathrm{~h}$, approximately $90 \%$ of the molecules of the $\mathrm{Ru}-\mathrm{BIP}$ present in the reaction mixture were bound to DNA. In these binding reactions, the time at which the binding reached 50\% $\left(t_{50}\right)$ was $\sim 10,15$, and $10 \mathrm{~min}$ and $3.5 \mathrm{~h}$ for the compounds $\mathrm{Ru}-\mathrm{BIP}, \mathrm{Ru}-\mathrm{DHA}, \mathrm{Ru}-\mathrm{THA}$, and $\mathrm{Ru}-\mathrm{CYM}$, respectively. The value of $t_{50} \%$ for the reaction of cisplatin with DNA under conditions identical to those specified in Figure 2 was $\sim 2 \mathrm{~h}$ (31).

The binding of $\mathrm{Ru}(\mathrm{II})$ arene compounds to CT DNA was also quantified in two other ways. Aliquots of the reaction mixture withdrawn at various time intervals were quickly cooled on an ice bath and then exhaustively dialyzed against $10 \mathrm{mM} \mathrm{NaClO}{ }_{4}$ at $4{ }^{\circ} \mathrm{C}$ or filtered using Sephadex G50 to remove free (unbound) ruthenium compound. The content of ruthenium in these DNA samples was determined by FAAS. Results identical to those obtained using the assay based on DNA precipitation by ethanol were obtained.

In further experiments, CT DNA was also incubated with the $\mathrm{Ru}(\mathrm{II})$ arene complexes at $r_{\mathrm{i}}=0.2$ and essentially a similar rate of binding was observed as for the reaction at $r_{\mathrm{i}}=0.1$. When $\mathrm{Ru}$ complexes were added to a higher level $\left(r_{\mathrm{i}}=0.25\right)$, the DNA precipitated immediately, probably due to electrostatic interactions between the positively charged $\mathrm{Ru}(\mathrm{II})$ arene complexes and DNA.

The binding experiments carried out in this work indicated that modification reactions resulted in the irreversible coordination of the $\mathrm{Ru}(\mathrm{II})$ arene complexes to polymeric double-helical DNA, which thus facilitated sample analysis. Hence, it was possible to prepare easily and precisely samples of DNA modified by the ruthenium complex at a preselected value of $r_{\mathrm{b}}$. Thus, except where stated, samples of DNA modified by $\mathrm{Ru}(\mathrm{II})$ arene compounds and analyzed further by biophysical or biochemical methods were prepared in 10 $\mathrm{mM} \mathrm{NaClO} 4$ at $37{ }^{\circ} \mathrm{C}$. After $24 \mathrm{~h}$ of the reaction of DNA with the complex, the samples were precipitated in ethanol and dissolved in the medium necessary for a particular analysis, and the $r_{\mathrm{b}}$ value in an aliquot of this sample was checked by FAAS. In this way, most of the analyses described in the present paper were performed in the absence of unbound (free) $\mathrm{Ru}(\mathrm{II})$ arene complex.

In Vitro Transcription of DNA Containing Ru(II) Arene Adducts. In vitro RNA synthesis by RNA polymerases on DNA templates containing several types of bifunctional 
A
SP6 pol.

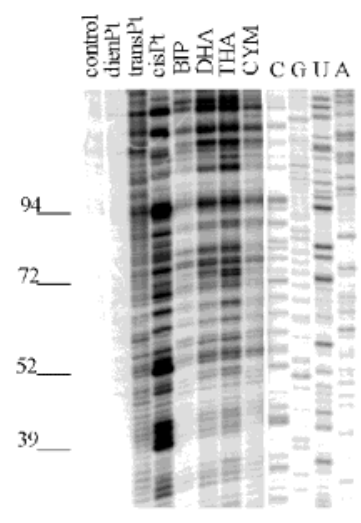

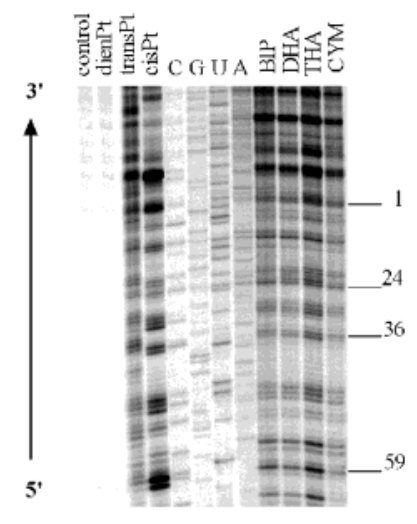

T7 pol.
B

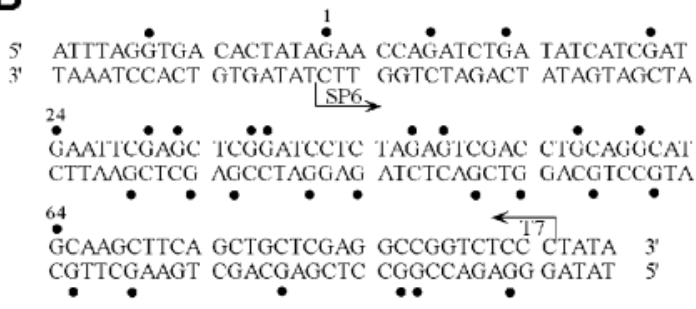

FIGURE 3: Inhibition of RNA synthesis by SP6 and T7 RNA polymerases on the $N d e \mathrm{I} / \mathrm{HpaI}$ fragment of pSP73KB plasmid modified by $\mathrm{Ru}(\mathrm{II})$ arene and platinum complexes. (A) Autoradiograms of $6 \%$ polyacrylamide/8 $\mathrm{M}$ urea sequencing gels showing inhibition of RNA synthesis by SP6 (left) or T7 RNA polymerases (right) on the $\mathrm{Nde} \mathrm{I} / \mathrm{HpaI}$ fragment containing adducts of ruthenium or platinum complexes. Lanes: control, unmodified template; BIP, DHA, THA, CYM, cisPt, transPt, and dienPt, the template modified by $\mathrm{Ru}-\mathrm{BIP}, \mathrm{Ru}-\mathrm{DHA}, \mathrm{Ru}-\mathrm{THA}, \mathrm{Ru}-\mathrm{CYM}$, cisplatin, transplatin, or $[\mathrm{Pt}($ dien $) \mathrm{Cl}] \mathrm{Cl}$ at $r_{\mathrm{b}}=0.01$, respectively; $\mathrm{A}, \mathrm{U}, \mathrm{G}$, and $\mathrm{C}$, chain terminated marker RNAs. (B) Schematic diagram showing the portion of the sequence used to monitor inhibition of RNA synthesis by ruthenium and platinum complexes. The arrows indicate the start of the SP6 and T7 RNA polymerase, which used as template the bottom or upper strand of the NdeI/HpaI fragment of pSP73KB DNA, respectively. ( ) major stop signals (from Figure 3A) for DNA modified by $\mathrm{Ru}-\mathrm{BIP}$. The numbers correspond to the nucleotide numbering in the sequence map of pSP73KB plasmid.

adducts of platinum complexes can be prematurely terminated at the level or in the proximity of adducts $(26,27)$. Importantly, monofunctional DNA adducts of several platinum complexes are unable to terminate RNA synthesis (26, 27, 32).

Cutting of pSP73KB DNA by NdeI and $\mathrm{HpaI}$ restriction endonucleases yielded a 212-bp fragment $(26,27)$ (a substantial part of its nucleotide sequence is shown in Figure 3B). This fragment contained SP6 or T7 RNA polymerase promotors [in both strands close to their 3'-ends (Figure 3B)]. The experiments were carried out using this linear DNA fragment modified by $\mathrm{Ru}(\mathrm{II})$ arene complexes, cisplatin, transplatin, or [ $\mathrm{Pt}(\mathrm{dien}) \mathrm{Cl}] \mathrm{Cl}$ at $r_{\mathrm{b}}=0.01$, for RNA synthesis by SP6 or T7 RNA polymerase (Figure 3A, lanes BIP, DHA, THA, CYM, cisDDP, transDDP, or dienPt, respectively). RNA synthesis on the fragment modified by the ruthenium and bifunctional platinum complexes yielded fragments of defined sizes, which indicates that RNA synthesis on these templates was prematurely terminated. The major stop sites produced by ruthenium compounds were identical for all four $\mathrm{Ru}$ (II) arene compounds $\mathrm{Ru}-\mathrm{BIP}, \mathrm{Ru}-\mathrm{DHA}, \mathrm{Ru}-\mathrm{THA}$, and $\mathrm{Ru}-\mathrm{CYM}(\mathrm{Ru}-\mathrm{BEN}$ was not studied in this assay) and were mainly at guanine residues. The corresponding bands on the autoradiogram were of similar intensity for the compounds $\mathrm{Ru}-\mathrm{BIP}, \mathrm{Ru}-\mathrm{DHA}$, and $\mathrm{Ru}-\mathrm{THA}$, whereas the bands produced by $\mathrm{Ru}-\mathrm{CYM}$ were markedly less intense. For comparative purposes, the inhibition of RNA synthesis by DNA adducts of cisplatin, transplatin, and monofunctional $[\mathrm{Pt}($ dien $) \mathrm{Cl}] \mathrm{Cl}$ is also shown (Figure $3 \mathrm{~A}$, lanes cisPt, trans $\mathrm{Pt}$, and dienPt) and demonstrates more termination for cisplatin but at the same termination sites as those for the $\mathrm{Ru}(\mathrm{II})$ arenes, different termination sites than those for transplatin, and no termination of RNA synthesis by monofunctional [Pt$($ dien $) \mathrm{Cl}] \mathrm{Cl}$. The sequence analysis reveals that the major bands resulting from termination of RNA synthesis by the adducts of cisplatin and $\mathrm{Ru}(\mathrm{II})$ arene compounds preferentially appear one or a half nucleotide preceding $\mathrm{G}$ sites and to a considerably less extent preceding A sites (in AGAG or AGGAG sequences). Taken together, Ru(II) arene compounds exhibit a base sequence selectivity similar to that of cisplatin. Nevertheless, the efficiency of the adducts of Ru(II) arene complexes to terminate RNA synthesis in vitro is in general reduced relative to that of cisplatin. Furthermore, the efficiency of the Ru-CYM complex was noticeably lower than that of the other three ruthenium compounds examined in this assay.

Circular and Linear Dichroism Spectroscopy. A sizable $\mathrm{CD}$ spectrum can be induced into the absorbance bands of a number of low-molecular-mass molecules upon their binding to double-helical DNA (33). Ideally, ligand absorbance bands that do not overlap with DNA bands (below $300 \mathrm{~nm}$ ) are used to probe the interaction. The $\mathrm{Ru}(\mathrm{II})$ arene compounds investigated here are achiral (not optically active) when free in solution. Binding of the $\mathrm{Ru}(\mathrm{II})$ arene complexes to DNA was indicated by the induction of a sizable CD spectrum for the $\mathrm{Ru}(\mathrm{II})-$ arene absorption bands [e.g. $\mathrm{Ru}(\mathrm{II})$ to arene $\pi^{*}$ charge-transfer transitions at $375 \mathrm{~nm}$ ] in the presence of double-helical DNA.

CD spectra for CT DNA in the absence and in the presence of increasing amounts of $\mathrm{Ru}(\mathrm{II})$ arene compounds bound to DNA are compared in Figure 4 (panels A-D). Binding of the compounds $\mathrm{Ru}-\mathrm{BIP}, \mathrm{Ru}-\mathrm{DHA}$, and $\mathrm{Ru}-\mathrm{THA}$ to $\mathrm{CT}$ DNA results in the appearance of a positive CD band centered around $370-380 \mathrm{~nm}$, and its intensity increased with the level of DNA ruthenation. Interestingly, the induced CD signal of $\mathrm{Ru}-\mathrm{BIP}$ was the largest, whereas the binding of $\mathrm{Ru}-\mathrm{CYM}$ to double-helical DNA resulted in no induced CD band in this region (Figure 4D). The different intensities of the induced $\mathrm{CD}$ bands produced by the compounds $\mathrm{Ru}-$ BIP, $\mathrm{Ru}-\mathrm{DHA}$, and $\mathrm{Ru}-\mathrm{THA}$ are, at least partly, due to the different extinction coefficients (ca. 380, 280, and 150 $\mathrm{M}^{-1} \mathrm{~cm}^{-1}$, respectively) of the free compounds at the wavelengths corresponding to this $\mathrm{CD}$ band.

Upon binding of $\mathrm{Ru}(\mathrm{II})$ arene compounds to CT DNA, the approximately conservative $\mathrm{CD}$ spectrum normally found for B-DNA at wavelengths below $300 \mathrm{~nm}$ (Figure 4A-D) is also changed. As a function of $r_{\mathrm{b}}$, there was a marked increase in the intensity of the positive band around $280 \mathrm{~nm}$ when DNA was modified by the compounds $\mathrm{Ru}-\mathrm{BIP}, \mathrm{Ru}-$ DHA, and Ru-THA, accompanied by a decrease in the intensity of the negative band at $245 \mathrm{~nm}$ (Figure 4A-C). This induced $\mathrm{CD}$ signal is due to changes in both the intrinsic DNA CD and the ligand-induced CD. On the other hand, when DNA was modified by $\mathrm{Ru}-\mathrm{CYM}$, no such increase 

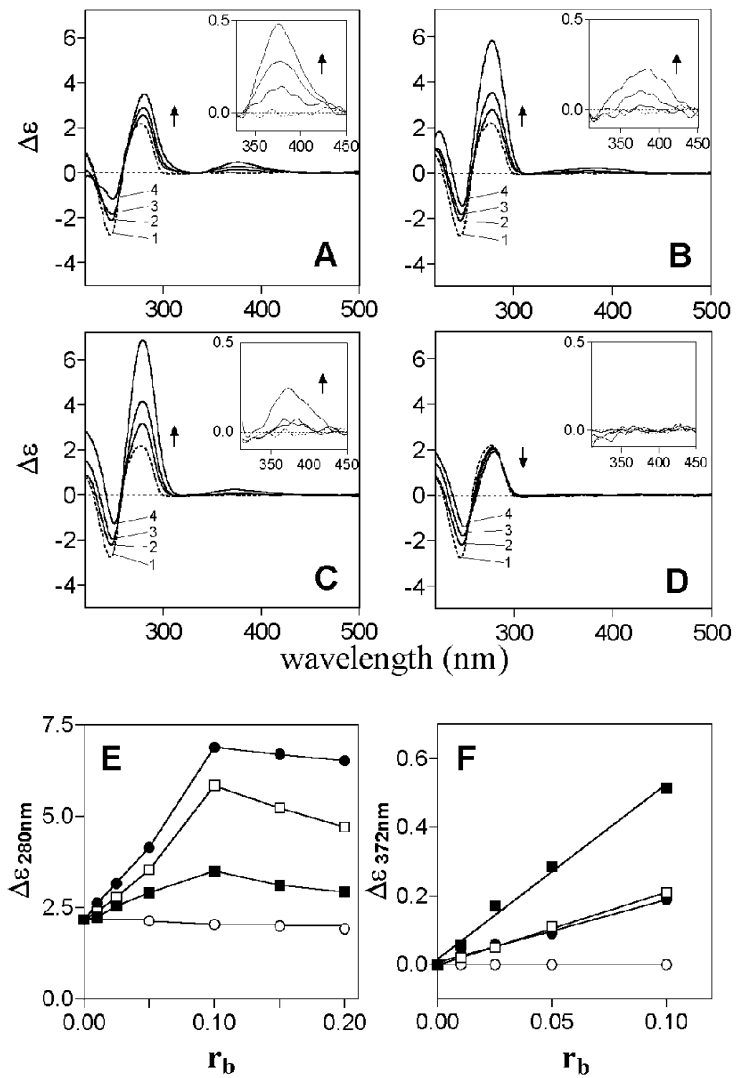

FIGURE 4: CD spectroscopy of calf thymus DNA modified by $\mathrm{Ru}(\mathrm{II})$ arene compounds. The spectra were recorded for DNA at the concentration $30 \mu \mathrm{g} / \mathrm{mL}$ in $10 \mathrm{mM} \mathrm{NaClO}_{4}$. (A-D) CD spectra of DNA modified by $\mathrm{Ru}-\mathrm{BIP}, \mathrm{Ru}-\mathrm{DHA}, \mathrm{Ru}-\mathrm{THA}$, or $\mathrm{Ru}-\mathrm{CYM}$, respectively. Curves in parts $\mathrm{A}-\mathrm{C}$ (from the bottom to the top at $\sim 250, \sim 275$, and $375 \mathrm{~nm}$ ): 1 (- - ), control (nonmodified) DNA; $2, r_{\mathrm{b}}=0.025 ; 3, r_{\mathrm{b}}=0.05 ; 4, r_{\mathrm{b}}=0.1$. Curves in part $\mathrm{D}($ at $\sim 250$ $\mathrm{nm}$, the order of appearance of the curves is the same as that given for $\mathrm{Ru}-\mathrm{BIP}, \mathrm{Ru}-\mathrm{DHA}$, and $\mathrm{Ru}-\mathrm{THA}$ in parts $\mathrm{A}-\mathrm{C}$, whereas it is reversed at $\sim 275 \mathrm{~nm}$ ): 1 (- - ), control (nonmodified) DNA; 2 , $r_{\mathrm{b}}=0.05 ; 3, r_{\mathrm{b}}=0.1 ; 4, r_{\mathrm{b}}=0.2$. Inset in parts A-D: a part of the CD spectrum (at $280-450 \mathrm{~nm}$ ) recorded at a higher sensitivity of the CD instrument. (E) Dependence of the maximum ellipticity of the positive $\mathrm{CD}$ band at around $280 \mathrm{~nm}$ on $r_{\mathrm{b}}$ : (品 $\mathrm{Ru}-\mathrm{BIP}$; ( $\square$ ) Ru-DHA; (@) Ru-THA; (O) Ru-CYM. (F) Dependence of the maximum ellipticity of the positive $\mathrm{CD}$ band at around $\sim 370$

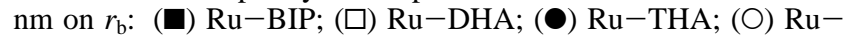
CYM. Data points measured in duplicate varied on average $\pm 1 \%$ from their mean.

in the intensity of the positive band around $280 \mathrm{~nm}$ was seen, but instead there was a small decrease.

We also recorded CD spectra of CT DNA and the synthetic double-stranded polynucleotide complexes poly (dG-dC) and poly $(\mathrm{dA}-\mathrm{dT})$ in the presence of these four Ru complexes and also the benzene complex $\mathrm{Ru}(\mathrm{BEN})$ at $r_{\mathrm{i}}=0.2$. An induced $\mathrm{CD}$ band at 350-410 nm was observed not only for interaction of $\mathrm{Ru}-\mathrm{BIP}, \mathrm{Ru}-\mathrm{THA}$, and $\mathrm{Ru}-\mathrm{DHA}$ with $\mathrm{CT}$ DNA but also for interaction with poly $(\mathrm{dG}-\mathrm{dC}$ ) (Figure $5 \mathrm{~A}$ and B). For poly(dG-dC), as for CT DNA, no induced band in the near UV region was observed for $\mathrm{Ru}-\mathrm{CYM}$, or for $\mathrm{Ru}-\mathrm{BEN}$ (Figure 5A and B). For poly(dA-dT), only the complexes with extended $\pi$ systems, $\mathrm{Ru}-\mathrm{BIP}, \mathrm{Ru}-\mathrm{THA}$, and $\mathrm{Ru}-\mathrm{DHA}$, induced any spectral changes, and these were small and confined to the region 260-280 nm (Figure 5C). These small changes may be due to weak hydrophobic interactions between the arene and the DNA bases. Neither
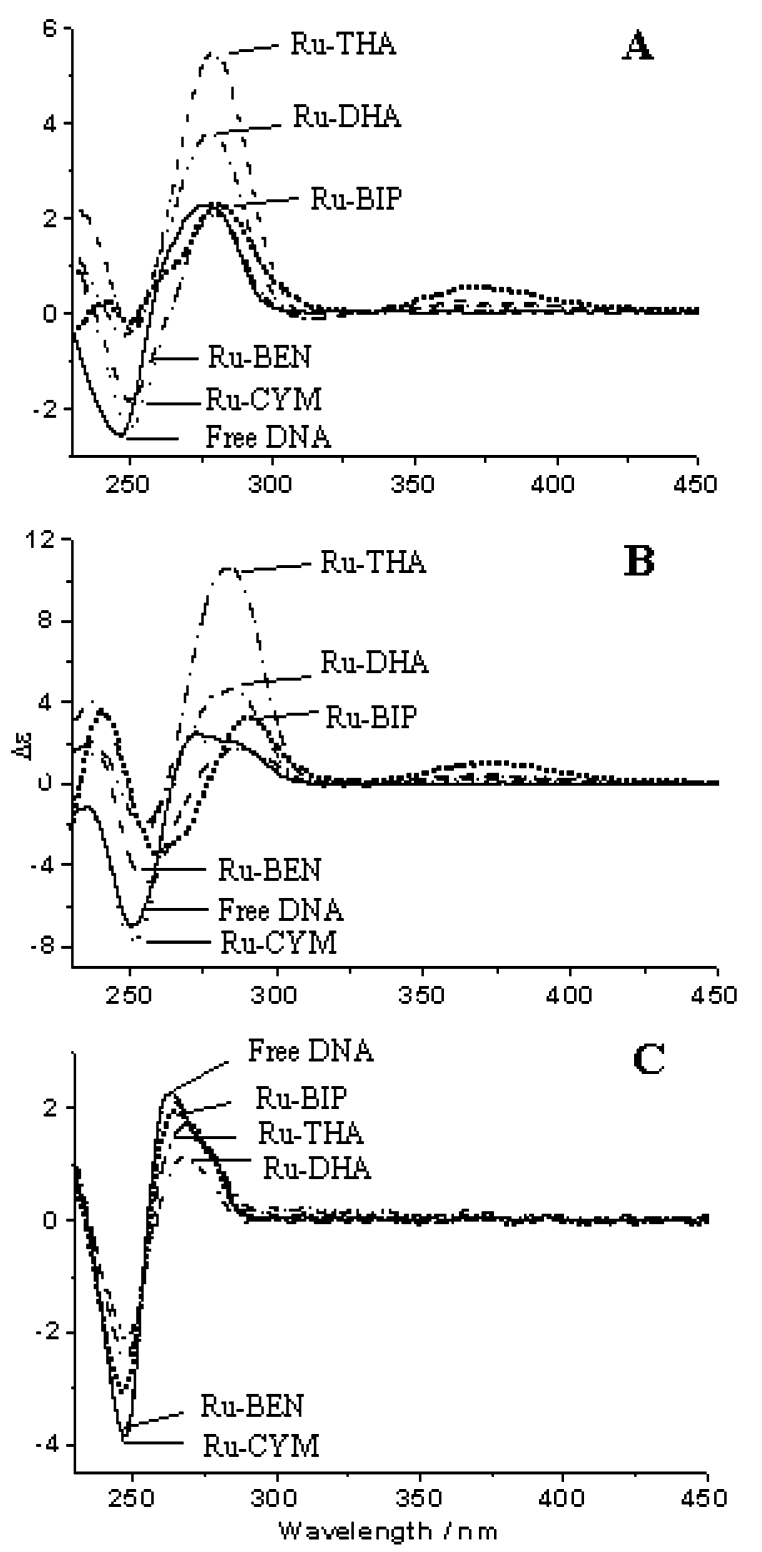

FIGURE 5: Comparisons of the effects of different arene ligands on the CD spectra of (A) CT DNA, (B) poly (dG-dC), and (C) poly(dA-dT) in $10 \mathrm{mM} \mathrm{NaClO}_{4}$ in the presence of various $\mathrm{Ru}$ (arene) complexes at $r_{\mathrm{i}}=0.2$. The spectra were recorded at $25^{\circ} \mathrm{C}$ after samples had been incubated for $24 \mathrm{~h}$ at $37^{\circ} \mathrm{C}$.

$\mathrm{Ru}-\mathrm{CYM}$ nor $\mathrm{Ru}-\mathrm{BEN}$ induced any spectral changes in poly(dA-dT).

The flow linear dichroism data for CT DNA (Figure S1A) resemble those of poly (dG-dC) DNA (Figure S1B) and show that the binding of all Ru complexes causes bending of the DNA. The three complexes $\mathrm{Ru}-\mathrm{THA}, \mathrm{Ru}-\mathrm{DHA}$, and $\mathrm{Ru}-$ BIP cause a significant red shift (ca. $10 \mathrm{~nm}$ ) of the main DNA band near $260 \mathrm{~nm}$, whereas the two complexes RuBEN and $\mathrm{Ru}-\mathrm{CYM}$ cause no shift. The wavelength shifts in the region of DNA absorption for $\mathrm{Ru}-\mathrm{THA}, \mathrm{Ru}-\mathrm{DHA}$, and $\mathrm{Ru}-\mathrm{BIP}$ are consistent with intercalation of the arene ligands, but the bending precludes full intercalation which would rigidify the DNA and thus increase the LD. Ru-BEN and $\mathrm{Ru}-\mathrm{CYM}$ complexes rigidify poly $(\mathrm{dA}-\mathrm{dT})$ DNA with no $260 \mathrm{~nm}$ band shift (Figure S1C); the other three complexes, $\mathrm{Ru}-\mathrm{DHA}, \mathrm{Ru}-\mathrm{THA}$, and $\mathrm{Ru}-\mathrm{BIP}$, cause significant bending while retaining sufficient orientation to produce an LD signal for these compounds. Ru-DHA 


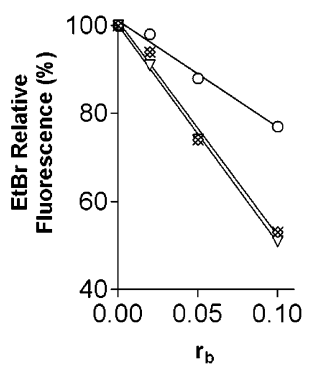

FIGURE 6: Dependences of the EtBr fluorescence on $r_{\mathrm{b}}$ for DNA modified by $\mathrm{Ru}\left(\right.$ arene) complexes in $10 \mathrm{mM} \mathrm{NaClO}{ }_{4}$ at $37^{\circ} \mathrm{C}$ for 24 h: $(\times) \mathrm{Ru}-\mathrm{BIP} ;(\diamond) \mathrm{Ru}-\mathrm{DHA} ;(\nabla) \mathrm{Ru}-\mathrm{THA} ;(\mathrm{O}) \mathrm{Ru}-\mathrm{CYM}$. Data points measured in triplicate varied on average $\pm 2 \%$ from their mean.

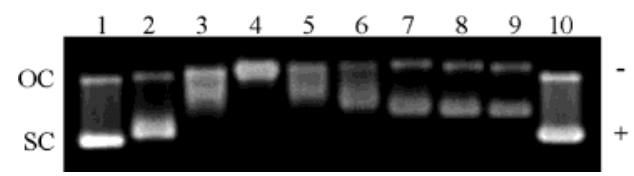

FIGURE 7: Unwinding of supercoiled pSP73KB plasmid DNA by the compound $\mathrm{Ru}-\mathrm{BIP}$. The plasmid was incubated with the ruthenium complex for $24 \mathrm{~h}$ at $37^{\circ} \mathrm{C}$. Lanes: 1 and 10, control, nonmodified DNA $\left(r_{\mathrm{b}}=0\right) ; 2, r_{\mathrm{b}}=0.03 ; 3, r_{\mathrm{b}}=0.06 ; 4, r_{\mathrm{b}}=$ $0.08 ; 5, r_{\mathrm{b}}=0.10 ; 6, r_{\mathrm{b}}=0.11 ; 7, r_{\mathrm{b}}=0.13 ; 8, r_{\mathrm{b}}=0.16 ; 9, r_{\mathrm{b}}=$ 0.17 . The top bands correspond to the form of nicked plasmid, and the bottom bands, to the closed, negatively supercoiled plasmid.

binding induces the most bending. The LD observed for the binding to poly $(\mathrm{dA}-\mathrm{dT})$ is consistent with a mode involving the aromatic ligands of $\mathrm{Ru}-\mathrm{DHA}, \mathrm{Ru}-\mathrm{THA}$, and $\mathrm{Ru}-\mathrm{BIP}$ inserted into the minor groove, giving a positive signal for the transitions in the $260-280 \mathrm{~nm}$ ligand y-polarized region and probably a negative one for the $240-255 \mathrm{~nm}$ z-polarized region (according to the film LD assignments, Figure S2).

Characterization of DNA Adducts by EtBr Fluorescence. $\mathrm{EtBr}$ as a fluorescent probe can be used to distinguish intercalating and nonintercalating ligands (34). Binding of $\mathrm{EtBr}$ to DNA by intercalation is blocked in a stoichiometric manner by formation of a wide spectrum of DNA-binding ligands including intercalators. On the other hand, modification of DNA by monofunctional nonintercalative ligands, such as $[\mathrm{Pt}($ dien $) \mathrm{Cl}] \mathrm{Cl}$, results in only a slight decrease of $\mathrm{EtBr}$ fluorescence intensity as compared with that for the complex of nonmodified DNA with EtBr. Competitive binding of other intercalators leads to a loss of fluorescence because of depletion of the DNA- $\mathrm{EtBr}$ complex (free $\mathrm{EtBr}$ is poorly fluorescent).

Double-helical DNA was modified by Ru arene compounds for $24 \mathrm{~h}$. The levels of the modification corresponded to the values of $r_{\mathrm{b}}$ in the range between 0 and 0.1 . Modification of DNA by $\mathrm{Ru}-\mathrm{BIP}, \mathrm{Ru}-\mathrm{DHA}$, and $\mathrm{Ru}-\mathrm{THA}$ resulted in a marked decrease of EtBr fluorescence (Figure 6). In contrast, the decrease of the fluorescence intensity by the adducts of $\mathrm{Ru}-\mathrm{CYM}$ was only very small and similar to that induced by the adducts of $[\mathrm{PtCl}($ dien $)] \mathrm{Cl}$ (35).

DNA Unwinding. Electrophoresis in native agarose gels was used to determine the unwinding induced in negatively supercoiled pSP73KB plasmid DNA by monitoring the degree of supercoiling (28) (Figure 7). A compound that unwinds the DNA duplex reduces the number of supercoils in closed circular DNA, which in turn causes a decrease in the rate of migration through the agarose gel.

Figure 7 shows an electrophoresis gel from experiments in which variable amounts of $\mathrm{Ru}-\mathrm{BIP}$ were bound to a
Table 1: Unwinding of Supercoiled pSP73KB DNA by Ru(II) Arene Complexes

\begin{tabular}{ccc}
\hline compd & $r_{\mathrm{b}}(\mathrm{c})$ & unwinding angle $^{a}$ \\
\hline $\mathrm{Ru}-\mathrm{BIP}$ & $0.08 \pm 0.005$ & $14 \pm 1^{\circ}$ \\
$\mathrm{Ru}-\mathrm{DHA}$ & $0.08 \pm 0.005$ & $14 \pm 1^{\circ}$ \\
$\mathrm{Ru}-\mathrm{THA}$ & $0.08 \pm 0.005$ & $14 \pm 1^{\circ}$ \\
$\mathrm{Ru}-\mathrm{CYM}$ & $0.16 \pm 0.01$ & $7 \pm 0.5^{\circ}$ \\
\hline
\end{tabular}

${ }^{a}$ The unwinding angle was calculated as described in the text.

mixture of relaxed and negatively supercoiled pSP73KB DNA. The mean unwinding angle is given by $\Phi=18 \sigma / r_{\mathrm{b}^{-}}$ (c), where $\sigma$ is the superhelical density and $r_{\mathrm{b}}(\mathrm{c})$ is the value of $r_{\mathrm{b}}$ at which the supercoiled and nicked forms comigrate (28). Under the present experimental conditions, $\sigma$ was calculated to be -0.063 on the basis of data for cisplatin for which the value $\Phi=13^{\circ}$ was used to determine $r_{\mathrm{b}}(\mathrm{c})$ (28). The $r_{\mathrm{b}}(\mathrm{c})$ values for all ruthenium arene compounds studied, along with the mean unwinding angles calculated in this way, are summarized in Table 1. The unwinding angles were 14 $\pm 1^{\circ}$ per bound $\mathrm{Ru}-\mathrm{BIP}, \mathrm{Ru}-\mathrm{DHA}$, and $\mathrm{Ru}-\mathrm{THA}$, and 7 $\pm 0.5^{\circ}$ for $\mathrm{Ru}-\mathrm{CYM}$.

DNA Melting. CT DNA was modified by $\mathrm{Ru}(\mathrm{II})$ arene compounds added at various $r_{\mathrm{b}}$ values $(0-0.1)$ in $10 \mathrm{mM}$ $\mathrm{NaClO}_{4}$ at $37{ }^{\circ} \mathrm{C}$ for $24 \mathrm{~h}$. The salt concentration was then further adjusted by addition of $\mathrm{NaClO}_{4}$ to values in the range 0.01-0.1 M. The effect on $t_{\mathrm{m}}$ is dependent both on the amount of ruthenium bound and on the salt concentration. At low concentrations of $\mathrm{NaClO}_{4}(0.01 \mathrm{M})$ an increase in $t_{\mathrm{m}}$ was observed for the three compounds $\mathrm{Ru}-\mathrm{BIP}, \mathrm{Ru}-\mathrm{DHA}$, and $\mathrm{Ru}-\mathrm{THA}$, and this became more pronounced with increasing $r_{\mathrm{b}}$ values (Figure 8A-C). With increasing ionic strength, the enhancement of $t_{\mathrm{m}}\left(\Delta t_{\mathrm{m}}\right)$ due to the presence of the $\mathrm{Ru}$ compounds decreased, and at salt concentrations of $0.2 \mathrm{M}, t_{\mathrm{m}}$ decreased. In contrast, the melting behavior of DNA modified by $\mathrm{Ru}-\mathrm{CYM}$ resulted in a similar decrease of $t_{\mathrm{m}}$ at all ionic strengths (Figure 8D).

Differential Pulse Polarography. This is a sensitive method for distinguishing between nondenaturational and denaturational conformational alterations in DNA induced by various physical or chemical agents (36). The analysis is based on the observation that intact double-helical DNA is polarographically inactive because its reduction sites are involved in hydrogen bonds and are unable to make contact with the working electrode in a manner suitable for electron transfer. Electroreduction of adenine or cytosine residues present in distorted but still double-stranded (nondenatured) regions of DNA is responsible for the appearance of the small DPP peak II (Figure 9A, curve 1). Base residues in these distorted regions become more accessible for electroreduction at the mercury electrode and can yield a small polarographic current. On the other hand, the appearance of a more negative peak III in DPP curves of DNA indicates the presence of single-stranded, denatured regions in the DNA molecule, in which hydrogen bonds between complementary bases have been broken (36). Differences in the adsorption properties of double-helical and denatured DNA at the mercury electrode have been suggested to give rise to the different reduction potentials observed for the two DNA conformations. Importantly, less than $1 \%$ of the denatured material in the presence of an excess of double-helical DNA can be determined by DPP (37). 

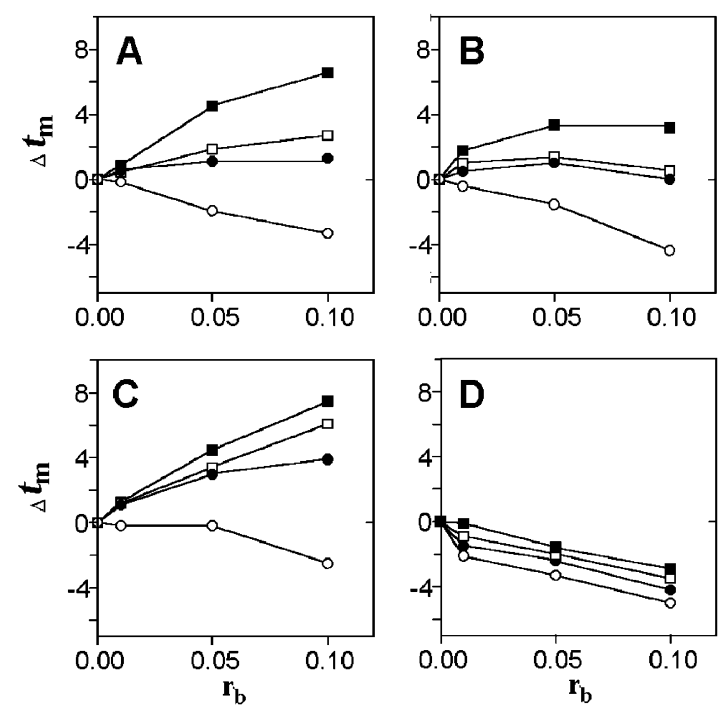

FIGURE 8: Plots showing the dependence of $\Delta t_{\mathrm{m}}$ values on $r_{\mathrm{b}}$ for calf thymus DNA modified by $\mathrm{Ru}(\mathrm{II})$ arene compounds: $\mathrm{A}, \mathrm{Ru}-$ $\mathrm{BIP}$; B, Ru-DHA; C, Ru-THA; D, Ru-CYM. The melting curves were measured in $0.01 \mathrm{M}(\mathbf{\square}), 0.05 \mathrm{M}(\square), 0.1 \mathrm{M}(\mathbf{})$, or $0.2 \mathrm{M}$ (O) $\mathrm{NaClO}_{4}$ plus $1 \mathrm{mM}$ Tris-HCl with $0.1 \mathrm{mM}$ EDTA, pH 7.4. $\Delta t_{\mathrm{m}}$ is defined as the difference between the $t_{\mathrm{m}}$ values of ruthenated and nonmodified DNAs. Data measured in triplicate varied on average $\pm 2 \%$ from their mean.

DPP has already been used to analyze DNA modified by various physical or chemical agents, including platinum and ruthenium compounds with different clinical efficacy (20, $38,39)$. It has been found that DNA globally modified by antitumor cisplatin, its antitumor analogues, or cis- or trans$\left[\mathrm{RuCl}_{2}\left(\mathrm{Me}_{2} \mathrm{SO}\right)_{4}\right]$ at $r_{\mathrm{b}}$ values up to 0.05 yields the more positive DPP peak II, indicating that these antitumor drugs induce nondenaturational conformational changes in DNA (38). In contrast, the more negative peak III is evident on DPP curves of DNA globally modified by clinically ineffective transplatin and other inactive platinum(II) complexes, indicating that the clinically ineffective platinum complexes induce denaturational conformational alterations in DNA $(38,39)$.

DPP analysis also sheds considerable light on the conformational basis for DNA binding of the $\mathrm{Ru}(\mathrm{II})$ arene compounds tested in this work. Modification of CT DNA by $\mathrm{Ru}-\mathrm{BIP}, \mathrm{Ru}-\mathrm{DHA}$ and $\mathrm{Ru}-\mathrm{THA}$ at $r_{\mathrm{b}}$ values of $0.0005-0.01$ resulted in an increase in intensity of the DPP peak II with increasing levels of the modification (shown for $\mathrm{Ru}-\mathrm{DHA}$ in Figure 9B). The more negative peak III was not detected even for the DPP curves recorded for DNA modified at the highest $r_{\mathrm{b}}$ value used in our experiments (0.01). As regards the DPP analysis of DNA modified by $\mathrm{Ru}$-THA, peak II was markedly distorted by a current corresponding to the higher background electrolyte discharge, so that the measurement of the height of this peak II at $r_{\mathrm{b}}$ values of 0.001 and higher was impossible. On the other hand, it was clear even from these distorted DPP curves that no peak III was present even at $r_{\mathrm{b}}=0.01$. It could be argued that the absence of peak III on the DPP curves recorded for the samples of DNA modified by $\mathrm{Ru}-\mathrm{BIP}, \mathrm{Ru}-\mathrm{DHA}$ and $\mathrm{Ru}$-THA at relatively high $r_{\mathrm{b}}$ values $(\sim 0.02)$ could be due to an increase in the slope of the part of the DPP curve corresponding to the background electrolyte discharge (Figure 9B, curve 4). The fact that peak III was not buried under the background electrolyte discharge curve was verified using
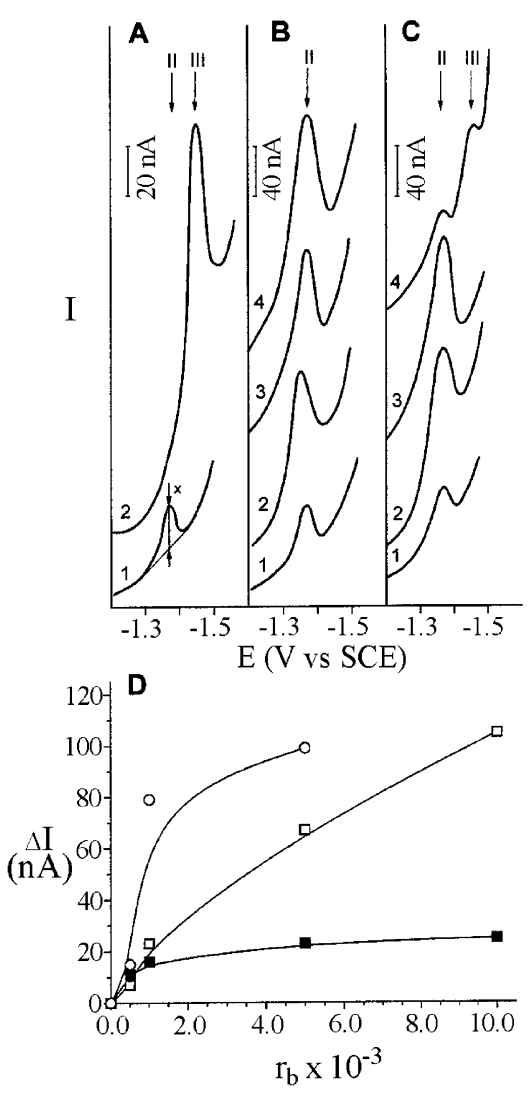

FIGURE 9: Differential pulse polarographic analysis of CT DNA modified by $\mathrm{Ru}(\mathrm{II})$ arene compounds. Double-helical DNA at a concentration of $0.32 \mathrm{mg} / \mathrm{mL}$ in $0.3 \mathrm{M}$ ammonium formate with $0.01 \mathrm{M}$ phosphate buffer, $\mathrm{pH}$ 6.8. (A) DPP curves of nonmodified DNA: 1, double-helical DNA; 2, thermally denatured DNA at the concentration of $0.030 \mathrm{mg} / \mathrm{mL}$. (B and C) DPP curves of doublehelical DNA modified by Ru-DHA (B) and Ru-CYM (C) at the following $r_{\mathrm{b}}$ values: $1,0.0005 ; 2,0.001 ; 3,0.005 ; 4,0.01$. The arrows in parts A-C marked by II and III indicate the potentials $E$ [against saturated calomel electrode (SCE)] at which native or denatured DNA samples yielded DPP peaks II or III, respectively (see the text). The procedure used to measure the height of the DPP peak $(x)$ in the present work is shown in Figure 9A, curve 1. (D) Dependence of the relative height of the DPP peak II, $\Delta I$, yielded by DNA modified by the ruthenium complexes on $r_{\mathrm{b}}$ : (ם) $\mathrm{Ru}-\mathrm{BIP}$; ( $\square) \mathrm{Ru}-\mathrm{DHA}$; (O) $\mathrm{Ru}-\mathrm{CYM}$. The value of $\Delta I$ was calculated as the ratio of the peak height yielded by the modified DNA over the peak height yielded by the control (nonmodified) DNA.

the samples of DNA modified by $\mathrm{Ru}-\mathrm{BIP}, \mathrm{Ru}-\mathrm{DHA}$ or $\mathrm{Ru}-\mathrm{THA}$ at $r_{\mathrm{b}}=0.01$ to which $0.8 \%$ thermally denatured calf thymus DNA was added. For this sample, a small, more negative peak III on the DDP curve (recorded under conditions specified for curve 4 in Figure 9B) was clearly observed (not shown). Thus, the absence of peak III on the DPP curves of DNA modified by $\mathrm{Ru}-\mathrm{BIP}, \mathrm{Ru}-\mathrm{DHA}$, or $\mathrm{Ru}$-THA suggests that these ruthenium complexes induce nondenaturational conformational distortions in DNA at relatively low levels of the global modification $\left(r_{\mathrm{b}} \leq 0.01\right)$, a behavior similar to that for the antitumor drug cisplatin and its antitumor analogues $(38,39)$. In contrast, a relative increase in the intensity of peak II due to the global modification by $\mathrm{Ru}-\mathrm{CYM}$ was also seen, but only at lower levels of the DNA modification $\left(r_{\mathrm{b}} \leq 0.005\right)$ (Figure 9C). At higher levels of DNA modification by $\mathrm{Ru}-\mathrm{CYM}$, a welldeveloped more negative DPP peak III, characteristic of the formation of single-stranded segments in double-helical 
DNA, was observed. This finding supports the view that the DNA binding mode of $\mathrm{Ru}-\mathrm{CYM}$ is different from that of the BIP, DHA, and THA ruthenium arene compounds and that the modification by $\mathrm{Ru}-\mathrm{CYM}$ may even lead to denaturational distortions of DNA.

\section{DISCUSSION}

Our studies of the binding of the $\mathrm{Ru}(\mathrm{II})$ arene ethylenediamine complexes $\mathrm{Ru}-\mathrm{BIP}, \mathrm{Ru}-\mathrm{DHA}$ and $\mathrm{Ru}-\mathrm{THA}$ to natural double-helical CT DNA show that the reactions are about an order of magnitude faster than that for cisplatin (Figure 2). However, the rate of binding is markedly dependent on the type of arene ligand: binding of $\mathrm{Ru}-\mathrm{CYM}$, a complex with a single arene ring and methyl and bulky isopropyl substituents, binds to CT DNA more slowly than cisplatin. The binding is almost quantitative in each case (>90\% after $24 \mathrm{~h}$ ), and the DNA-Ru adducts are stable, with little loss of bound $\mathrm{Ru}$ after extensive dialysis. Transcription mapping experiments (Figure 3) have shown that guanine residues are the preferential binding sites when polymeric DNA is modified with $\mathrm{Ru}(\mathrm{II})$ arene complexes in a random fashion.

The selectivity of these pseudo-octahedral $\mathrm{Ru}(\mathrm{II})$ arene ethylenediamine complexes for $G$ bases was also found previously in our studies of model reactions of monomeric nucleosides and nucleotides $(23,40) . \mathrm{Ru}(\mathrm{II})$ in arene ethylenediamine complexes bind strongly to GN7, and C6O of $\mathrm{G}$ can then form a strong intramolecular H-bond with an $\mathrm{NH}$ of the coordinated ethylenediamine $(23,40)$. For adenine and cytosine unfavorable interactions between the amino groups on these bases and the amino groups of coordinated en have been demonstrated $(23,40)$. Binding to thymine N3 requires displacement of the $\mathrm{N} 3 \mathrm{H}$ proton, which is not favorable at $\mathrm{pH}$ values in the physiological range and not accessible in double-helical DNA. Also, when the arene contains an extended $\pi$-electron system, as in biphenyl or the anthracene derivatives studied in this work, an additional stabilization of the interaction can arise from hydrophobic $\pi-\pi$ stacking of the coordinated arene ring system with the purine ring $(23,40)$. Such hydrophobic $\pi-\pi$ stacking is enhanced when one or both partners are electron-poor (41). $\mathrm{Ru}(\mathrm{II})$ binding to $\mathrm{G}$ N7 decreases the electron density on the purine but increases electron density on $\mathrm{Ru}(\mathrm{II})$ which, in turn, enhances $\pi$-back-bonding of $\mathrm{Ru}$ (II) to the $\eta^{6}$-arene (42).

Slower reactions between CT DNA and $\mathrm{Ru}-\mathrm{CYM}$ (Figure 1), or $\mathrm{Ru}-\mathrm{BEN}$, compared to $\mathrm{Ru}-\mathrm{BIP}, \mathrm{Ru}-\mathrm{DHA}$ and $\mathrm{Ru}-$ THA are expected from our model studies of the kinetics of binding of these complexes to cyclic-3', $5^{\prime}$-GMP (23). Reactions of $\mathrm{Ru}-\mathrm{BIP}, \mathrm{Ru}-\mathrm{DHA}$ and $\mathrm{Ru}-\mathrm{THA}$ with cGMP are greater than three times faster. This difference may arise from the ability of the extended $\pi$ system of the arene ligand in the faster-reacting complexes to take part in hydrophobic $\pi-\pi$ stacking interactions with the purine ring of $\mathrm{G}$, as observed in model complexes. This is not possible for the monoarene complexes $\mathrm{Ru}-\mathrm{CYM}$ or $\mathrm{Ru}-\mathrm{BEN}$, since the $\pi$-electron system of these ligands is fully involved in coordination to $\mathrm{Ru}(\mathrm{II})$. Hence, it is reasonable to suggest that hydrophobic interactions can contribute to the driving force for the binding of chloro $\mathrm{Ru}(\mathrm{II})$ arene complexes to doublehelical DNA.
By analogy with the changes in the CD spectra and DPP behavior of DNA modified by cisplatin and antitumorinactive transplatin or $[\mathrm{Pt}(\operatorname{dien}) \mathrm{Cl}] \mathrm{Cl}$, it is reasonable to suggest that the binding of $\mathrm{Ru}-\mathrm{BIP}, \mathrm{Ru}-\mathrm{DHA}$, and $\mathrm{Ru}-$ THA results in conformational alterations in double-helical DNA of nondenaturational character, as is the case for DNA modification by antitumor cisplatin (38). The CD and DPP results (Figures 4, 5, and 9) also suggest that the conformational changes induced in DNA by $\mathrm{Ru}-\mathrm{CYM}$ and $\mathrm{Ru}-\mathrm{BEN}$ are different from those induced by the other three ruthenium arene compounds and, in contrast, are of denaturational character, similar to the case of DNA modification by transplatin or monofunctional $[\mathrm{Pt}(\operatorname{dien}) \mathrm{Cl}] \mathrm{Cl}$ complexes. The $\mathrm{LD}$ data (Figures $\mathrm{S} 1$ and $\mathrm{S} 2$ ) showed that $\mathrm{Ru}-\mathrm{CYM}$ stiffened poly(dA-dT) DNA, while the other complexes bend it, and for $\mathrm{Ru}-\mathrm{BIP}, \mathrm{Ru}-\mathrm{DHA}$, and $\mathrm{Ru}-\mathrm{THA}$ the main effect of binding to poly (dG-dC) and CT-DNA appears to be the induction of DNA bending, making it difficult to draw conclusions about the local orientations of the complexes on the DNA. The coordination of $\mathrm{Ru}-\mathrm{BIP}, \mathrm{Ru}-\mathrm{DHA}$, or $\mathrm{Ru}$-THA to double-helical DNA also results in the appearance of a CD band centered around 370-380 nm (Figure $4 \mathrm{~A}-\mathrm{C}$ ). The induced $\mathrm{CD}$ bands for achiral molecules bound to DNA arise either from coupling between the dipole transition moment of the nucleobases and the bound metal complex or from distortion of the geometry of the metal complex. Since binding of neither Ru-CYM (Figure 4D) nor $\mathrm{Ru}-\mathrm{BEN}$ (Figure 5) to DNA gives rise to such a CD band in this region of the spectrum, and these complexes contain only a single ring, it seems likely that the metalcentered induced band is related either to intercalation of the extended arene ligands into DNA or to groove binding. The observation of such bands is well documented for other intercalating metal complexes $(43,44)$. For example, the binding of [Pt(terpyridine $\left.)\left(\mathrm{CH}_{3}\right)\right]^{+}$to DNA at $r_{\mathrm{i}}=0.1$ gives rise to positive $C D$ bands at $315-340 \mathrm{~nm}$, indicating possible intercalation of the terpyridine ligand (45). Similar CD bands were observed for binding of $\mathrm{Ru}$ (II) arene complexes to poly(dG-dC) as for CT DNA (Figure 5A,B), but not for poly(dA-dT) (Figure 5C). From model studies of mononucleotides $(23,40)$, only weak binding to A or $\mathrm{T}$ is expected, accounting for the differences in binding to poly(dA-dT). From the assignments made by film LD experiments, the effects on the LD spectrum of poly(dA-dT) DNA are consistent with a binding mode involving insertion of the extended $\pi$-systems of $\mathrm{Ru}-\mathrm{DHA}, \mathrm{Ru}-\mathrm{THA}$, and $\mathrm{Ru}-\mathrm{BIP}$ into the minor groove, giving a positive signal for the transitions in the 260-280 nm ligand y-polarized region and probably a negative signal for the $240-255 \mathrm{~nm}$ z-polarized region.

The CD changes observed for double-helical DNA modified by the $\mathrm{Ru}(\mathrm{II})$ arene compounds also correlate with the results of DNA unwinding (Figure 7 and Table 1) and competitive EtBr displacement (Figure 6) experiments. The monofunctional adducts of $\mathrm{Ru}-\mathrm{BIP}, \mathrm{Ru}-\mathrm{DHA}$, or $\mathrm{Ru}-\mathrm{THA}$ are considerably more efficient in DNA-EtBr fluorescence quenching and in DNA unwinding than those of $\mathrm{Ru}-\mathrm{CYM}$. One plausible explanation for this observation may be an associated large additional contribution to fluorescence quenching and unwinding from intercalation of the extended arene ligand of the compounds $\mathrm{Ru}-\mathrm{BIP}, \mathrm{Ru}-\mathrm{DHA}$, or $\mathrm{Ru}-\mathrm{THA}$ into the duplex or from other types of 
noncovalent interaction of these complexes with DNA upon their monofunctional binding. The large unwinding angles of 15 or $19^{\circ}$ produced by the platinum compounds cis-[Pt$\left(\mathrm{NH}_{3}\right)_{2}(\mathrm{~N} 3$-ethidium $\left.) \mathrm{Cl}\right]^{2+}$ and cis- $\left[\mathrm{Pt}\left(\mathrm{NH}_{3}\right)_{2}(\mathrm{~N} 8\right.$-ethidium $)$ $\mathrm{Cl}]^{2+}$, respectively, which incorporate the well-known DNA intercalator ethidium and which can form only monofunctional adducts with DNA, have been explained in this way (28). Thus, the arene moiety in the monofunctional adducts of the compounds $\mathrm{Ru}-\mathrm{BIP}, \mathrm{Ru}-\mathrm{DHA}$, and $\mathrm{Ru}-\mathrm{THA}$ could be geometrically well positioned to intercalate between the base pairs of the helix, so producing also the induced CD bands (Figure 5). Consistent with this conclusion is the observation that the adducts of the compound $\mathrm{Ru}-\mathrm{CYM}$, which (like $\mathrm{Ru}-\mathrm{BEN}$ ) produces no induced $\mathrm{CD}$ bands in the visible spectrum and quenches DNA-EtBr fluorescence only slightly, unwinds DNA only by $7^{\circ}$ (Figure 7D, Table 1), a similar behavior to that of the monofunctional adducts of $[\mathrm{Pt}(\mathrm{dien}) \mathrm{Cl}] \mathrm{Cl}$ [unwinding angle $\left.6^{\circ}(28)\right]$. Thus, the results of unwinding experiments support the view that the arene ligand in $\mathrm{Ru}-\mathrm{BIP}, \mathrm{Ru}-\mathrm{DHA}$, and $\mathrm{Ru}-\mathrm{THA}$ interacts substantially with the double helix upon coordination of the ruthenium complex. Hence, these results strengthen the case for combined intercalative and monofunctional binding modes which may be facilitated by the fluxionality of the arene ligand in these complexes (40). On the other hand, it seems reasonable to suggest that the $p$-cymene and benzene ligands in the compounds $\mathrm{Ru}-\mathrm{CYM}$ do not interact with the double helix in a similar way, thus also supporting a different DNA binding mode for these compounds in comparison with the other three $\mathrm{Ru}(\mathrm{II})$ arene complexes studied in the present work.

The arene-purine hydrophobic interactions and/or arenebase stacking involved in the binding of the arene compounds to double-helical DNA may also affect its melting behavior. Previously, three factors have been invoked to account for the thermal stability of DNA modified by ruthenium and platinum complexes: stabilizing effects of the positive charge on the ruthenium and platinum moieties and of DNA interstrand cross-links, and a destabilizing effect of conformational distortions such as intrastrand cross-links induced in DNA by ruthenium and platinum coordination. At least two additional factors may be involved in DNA stabilization by intercalators: (i) favorable stacking interactions between the base residues and the intercalator, and (ii) the separation of negative backbone charges inherent to intercalation (due to elongation and unwinding of DNA), that is, changes in solvent structure and the counterion distribution around the phosphate groups which may help to overcome electrostatics unfavorable for the hybridization of the strands of the duplex $(46,47)$. The dependence of the transition melting temperature of DNA modified by nonintercalating platinum or ruthenium drugs on ionic strength can be explained by competing electrostatic effects as the salt concentration is varied (48). Under the incubation conditions, we expect all $\mathrm{Ru}$ (II) arene complexes to have produced monofunctional adducts so that the effect of interstrand cross-links need not be considered. Thus, the observed change in melting temperature will reflect the relative proportion and contribution of all limiting binding modes. Inherently, we predict that conformational distortions due to the formation of the adducts will destabilize the helix, as has been consistently observed in earlier studies with various ruthenium and platinum compounds.

At low ionic strength $(0.01 \mathrm{M})$, it is reasonable to conclude that the increases in $t_{\mathrm{m}}$ due to the modification of DNA by $\mathrm{Ru}-\mathrm{BIP}, \mathrm{Ru}-\mathrm{DHA}$, or $\mathrm{Ru}-\mathrm{THA}$ (Figure $8 \mathrm{~A}-\mathrm{C}$ ) are caused by the positive charges on ruthenium $\{(\operatorname{arene}) \mathrm{Ru}(\mathrm{en})\}^{+}$ moieties and by the intercalation. An interesting and as yet unresolved question, therefore, is why the modification of DNA by these three $\mathrm{Ru}(\mathrm{II})$ arene compounds appears to result in smaller thermal stabilization or even destabilization if the melting curves are measured at high salt concentrations. It is possible that the smaller increase or decrease in $t_{\mathrm{m}}$ due to the modification by the compounds $\mathrm{Ru}-\mathrm{BIP}, \mathrm{Ru}-\mathrm{DHA}$, and $\mathrm{Ru}-\mathrm{THA}$ and observed at high ionic strength is a consequence of conformational changes induced by the adducts of these $\mathrm{Ru}$ (II) arene compounds that then compensate more efficiently the "stabilizing" effects. At high salt concentration the stabilizing effects due to the modification of DNA by $\mathrm{Ru}-\mathrm{BIP}, \mathrm{Ru}-\mathrm{DHA}$, or $\mathrm{Ru}-\mathrm{THA}$ are reduced, since the electrostatic effects of these compounds are apparently lowered with increasing concentration of $\mathrm{Na}^{+}$counterions.

As pointed out above, the melting behavior of DNA modified by the compound $\mathrm{Ru}-\mathrm{CYM}$ is different (cf. parts $\mathrm{A}-\mathrm{C}$ and $\mathrm{D}$ of Figure 8). Modification by $\mathrm{Ru}-\mathrm{CYM}$ already decreases $t_{\mathrm{m}}$ at low concentrations of $\mathrm{Na}^{+}$, indicating that the effects of the factors responsible for the thermal stabilization of DNA are noticeably reduced. As also mentioned above, two factors have been invoked to account for the increase of the thermal stability of DNA due to the modification by $\mathrm{Ru}(\mathrm{II})$ arene complexes: stabilizing effects of the positive charge on the ruthenium atom and those associated with intercalation of the arene ligand in these ruthenium compounds into the duplex. Hence, it seems reasonable to conclude that the effect of one or both these factors is markedly reduced so that the destabilization effect of conformational alterations induced by $\mathrm{Ru}-\mathrm{CYM}$ predominates already at low salt concentrations. The results are consistent with the formation of a monofunctional adduct of $\mathrm{Ru}-\mathrm{CYM}$ with DNA (coordination to G N7) and the absence of intercalation, as expected for this substituted single-ring arene ligand. Hence, the stabilization of DNA typical of intercalators (vide supra) would not be effective, for obvious reasons. In addition, the stabilizing effects of the positive charge on the ruthenium atom of the compound $\mathrm{Ru}-\mathrm{CYM}$ might be considerably reduced due to a substantially different location of the ruthenium atom in the adduct of $\mathrm{Ru}-\mathrm{CYM}$ relative to the DNA sugar-phosphate backbone. This location might be unfavorable from the viewpoint of the efficiency of the positive charge on the ruthenium atom to neutralize negative charges of DNA phosphate groups. The suggestion that the positive charge on the ruthenium atom in the adducts of $\mathrm{Ru}-\mathrm{CYM}$ does not markedly contribute to the thermal stability of DNA is also consistent with the observation that the lowering of the melting temperature of DNA due to modification by $\mathrm{Ru}-$ CYM is almost independent of the $\mathrm{Na}^{+}$concentration (Figure 8D). Thus, the solution behavior of the DNA adducts of $\mathrm{Ru}(\mathrm{II})$ arene complexes appears interesting and merits further study.

Circular dichroism and polarographic analyses of DNA modified by $\mathrm{Ru}(\mathrm{II})$ arene anticancer compounds (Figures 4 , 5 , and 9) demonstrate that the formation of the monofunctional adducts of these complexes distorts the DNA confor- 
mation. The compounds $\mathrm{Ru}-\mathrm{BIP}, \mathrm{Ru}-\mathrm{DHA}$, or $\mathrm{Ru}-\mathrm{THA}$, which contain arene ligands with extended $\pi$-systems, induce nondenaturational alterations in DNA. On the other hand, the adducts of $\mathrm{Ru}-\mathrm{CYM}$, which contains a single arene ring but with methyl and bulky isopropyl substituents, distort DNA more severely, so that even denaturational changes may occur. The mechanisms underlying the biological effects of antitumor metal-based drugs may also involve further "downstream" effects of damaged DNA. These effects include processing of DNA adducts of these compounds by cellular components, for example, recognition of the adducts by specific proteins, and their repair $(49,50)$. This processing may also be affected by both the character of the conformational alterations induced in DNA and the resulting thermodynamic destabilization of this polynucleotide. For instance, minor 1,3-intrastrand cross-links of cisplatin, which probably do not contribute significantly to the antitumor effects of this drug, or the same adducts of its clinically ineffective trans isomer induce denaturational alterations in DNA (51). On the other hand, nondenaturational alterations occur in DNA as a consequence of the formation of the major 1,2-intrastrand cross-link of cisplatin (52). Interestingly, it has been shown that high-mobility-group (HMG)-domain proteins play an important role in the antitumor effect of cisplatin in several tumor cell lines $(49,50)$, and while the 1,2-intrastrand cross-link of cisplatin is recognized by these proteins (53), the 1,3-intrastrand cross-links of cisplatin or transplatin are not $(50,53)$. In addition, the 1,3-intrastrand cross-links of cisplatin are more readily removed from DNA than its major 1,2-intrastrand cross-links (54), and it has been shown $(49,55)$ that enhanced repair of the adducts of cisplatin contributes to enhanced resistance to this drug. Thus, an intriguing eventuality for future research is to correlate different DNA binding modes of $\mathrm{Ru}-\mathrm{CYM}$ and $\mathrm{Ru}-\mathrm{BEN}$ and the other three $\mathrm{Ru}(\mathrm{II})$ arene compounds tested in the present work with their cytotoxicity in tumor cell lines.

In summary, the present work demonstrates that the concept based on $\mathrm{Ru}(\mathrm{II})$ arene complexes represents an interesting possibility for studies aimed at improving knowledge of the mechanisms underlying the biological effects of ruthenium compounds. Whether this concept is applicable to the development of new anticancer drugs has still to be examined.

\section{SUPPORTING INFORMATION AVAILABLE}

Flow linear dichroism spectra of CT, poly $(\mathrm{dG}-\mathrm{dC})$, and poly(dA-dT) DNA after reaction with $\mathrm{Ru}(\mathrm{II})$ arene complexes (Figure S1), and determination of transition polarizations of dihydroanthracene (Figure S2). This material is available free of charge via the Internet at http://pubs.acs.org.

\section{REFERENCES}

1. Johnson, N. P., Butour, J.-L., Villani, G., Wimmer, F. L., Defais, M., Pierson, V., and Brabec, V. (1989) Prog. Clin. Biochem. Med. $10,1-24$

2. Brabec, V. (2000) in Platinum-Based Drugs in Cancer Therapy (Kelland, L. R., and Farrell, N. P., Eds.) pp 37-61, Humana Press Inc., Totowa, NJ.

3. Fichtinger-Schepman, A. M. J., Van der Veer, J. L., Den Hartog, J. H. J., Lohman, P. H. M., and Reedijk, J. (1985) Biochemistry 24, 707-713.

4. Eastman, A. (1987) Pharmacol. Ther. 34, 155-166.
5. Cleare, M. J. (1974) Coord. Chem. Rev. 12, 349-405.

6. Cleare, M. J. (1977) J. Clin. Hematol. Oncol. 7, 1-25.

7. Farrell, N. (1996) in Metal Ions in Biological Systems (Sigel, A., and Sigel, H., Eds.) pp 603-639, Marcel Dekker, Inc., New York, Basel, Hong Kong.

8. Brabec, V., Kasparkova, J., Vrana, O., Novakova, O., Cox, J. W., Qu, Y., and Farrell, N. (1999) Biochemistry 38, 6781-6790.

9. Farrell, N. (2000) in Platinum-Based Drugs in Cancer Therapy (Kelland, L. R., and Farrell, N. P., Eds.) pp 321-338, Humana Press Inc., Totowa, NJ.

10. Keppler, B. K. (1993) Metal Complexes in Cancer Chemotherapy, VCH Verlagsgesellschaft, VCH Publishers, Weinheim, New York.

11. Sava, G., and Bergamo, A. (2000) Int. J. Oncol. 17, 353-365.

12. Clarke, M. J. (2003) Coord. Chem. Rev. 236, 209-233.

13. Aird, R., Cummings, J., Ritchie, A., Muir, M., Morris, R., Chen, H., Sadler, P., and Jodrell, D. (2002) Br. J. Cancer 86, 16521657.

14. Morris, R. E., Aird, R. E., Murdoch, P. D., Chen, H. M., Cummings, J., Hughes, N. D., Parsons, S., Parkin, A., Boyd, G., Jodrell, D. I., and Sadler, P. J. (2001) J. Med. Chem. 44, 36163621.

15. Sava, G., Alessio, E., Bergano, A., and Mestroni, G. (1999) in Topics in Biological Inorganic Chemistry. Metallopharmaceuticals I (Clarke, M. J., and Sadler, P. J., Eds.) pp 143-169, Springer, Berlin.

16. Clarke, M. J., Zhu, F., and Frasca, D. R. (1999) Chem. Rev. 99 , 2511-2533.

17. Sava, G., Pacor, S., Coluccia, M., Mariggio, M., Cocchietto, M., Alessio, E., and Mestroni, G. (1994) Drug Invest. 8, 150-161.

18. Novakova, O., Kasparkova, J., Vrana, O., van Vliet, P. M., Reedijk, J., and Brabec, V. (1995) Biochemistry 34, 12369-12378.

19. Barca, A., Pani, B., Tamaro, M., and Russo, E. (1999) Mutation Res. 423, 171-181.

20. Novakova, O., Hofr, C., and Brabec, V. (2000) Biochem. Pharmacol. 60, 1761-1771.

21. Malina, J., Novakova, O., Keppler, B. K., Alessio, E., and Brabec, V. (2001) J. Biol. Inorg. Chem. 6, 435-445.

22. Wang, F., Chen, H., Parsons, S., Oswald, I. D. H., Davidson, J. E., and Sadler, P. J. (2003) Chem. Eur. J., in press.

23. Chen, H. M., Parkinson, J. A., Morris, R. E., and Sadler, P. J. (2003) J. Am. Chem. Soc. 125, 173-186.

24. Brabec, V., and Palecek, E. (1970) Biophysik 6, 290-300.

25. Brabec, V., and Palecek, E. (1976) Biophys. Chem. 4, 76-92.

26. Lemaire, M. A., Schwartz, A., Rahmouni, A. R., and Leng, M. (1991) Proc. Natl. Acad. Sci. U.S.A. 88, 1982-1985.

27. Brabec, V., and Leng, M. (1993) Proc. Natl. Acad. Sci. U.S.A. 90, 5345-5349.

28. Keck, M. V., and Lippard, S. J. (1992) J. Am. Chem. Soc. 114, 3386-3390.

29. Butour, J. L., and Macquet, J. P. (1977) Eur. J. Biochem. 78, 455463.

30. Butour, J. L., Alvinerie, P., Souchard, J. P., Colson, P., Houssier, C., and Johnson, N. P. (1991) Eur. J. Biochem. 202, 975-980.

31. Bancroft, D. P., Lepre, C. A., and Lippard, S. J. (1990) J. Am. Chem. Soc. 112, 6860-6871.

32. Brabec, V., Boudny, V., and Balcarova, Z. (1994) Biochemistry $33,1316-1322$.

33. Rodger, A., and Norden, B. (1997) Circular Dichroism and Linear Dichroism, Oxford University Press, Oxford, New York, Tokyo.

34. Jenkins, T. C. (1997) in Drug-DNA Interaction Protocols (Fox, K. R., Ed.) pp 195-218, Humana Press Inc., Totowa, NJ.

35. Marini, V., Kasparkova, J., Novakova, O., Scolaro, L. M., Romeo, R., and Brabec, V. (2002) J. Biol. Inorg. Chem. 7, 725-734.

36. Palecek, E. (1983) in Topics in Bioelectrochemistry and Bioenergetics (Milazzo, G., Ed.) pp 65-155, John Wiley and Sons, Ltd., New York.

37. Palecek, E. (1971) Methods Enzymol. 21, 3-24.

38. Brabec, V., Kleinwächter, V., Butour, J. L., and Johnson, N. P. (1990) Biophys. Chem. 35, 129-141.

39. Vrana, O., Kleinwächter, V., and Brabec, V. (1984) Experientia 40, 446-451

40. Chen, H. M., Parkinson, J. A., Parsons, S., Coxall, R. A., Gould, R. O., and Sadler, P. J. (2002) J. Am. Chem. Soc. 124, 30643082 .

41. Janiak, C. (2000) J. Chem. Soc., Dalton Trans., 3885-3896.

42. Stebler-Röthlisberger, M., Hummel, W., Pittet, P.-A., Bürgi, H.B., Ludi, A., and Merbach, A. E. (1988) Inorg. Chem. 27, $1358-$ 1363. 
43. Long, E. C., and Barton, J. K. (1990) Acc. Chem. Res. 23, $271-$ 273.

44. Lyng, R., Rodger, A., and Norden, B. (1991) Biopolymers 31 1709-1720.

45. Arena, G., Monsu Scolaro, L., Pasternack, R. F., and Romeo, R. (1995) Inorg. Chem. 34, 2994-3002.

46. Maeda, Y., Nunomura, K., and Ohtsubo, E. (1990) J. Mol. Biol. $215,321-329$.

47. Bjorndal, M. T., and Fygenson, D. K. (2002) Biopolymers 65, 40-44.

48. Zaludova, R., Kleinwächter, V., and Brabec, V. (1996) Biophys. Chem. 60, 135-142.

49. Cohen, S. M., and Lippard, S. J. (2001) in Prog. Nucleic Acid Res. Mol. Biol. (Moldave, K., Ed.) pp 93-130, Academic Press Inc., San Diego, CA.
50. Brabec, V. (2002) in Prog. Nucleic Acid Res. Mol. Biol. (Moldave, K., Ed.) pp 1-68, Academic Press Inc., San Diego, CA.

51. Anin, M. F., and Leng, M. (1990) Nucleic Acids Res. 18, 43954400.

52. Gelasco, A., and Lippard, S. J. (1999) in Topics in Biological Inorganic Chemistry. Metallopharmaceuticals I (Clarke, M. J., and Sadler, P. J., Eds.) pp 1-43, Springer, Berlin.

53. Jamieson, E. R., and Lippard, S. J. (1999) Chem. Rev. 99, 24672498.

54. Zamble, D. B., Mu, D., Reardon, J. T., Sancar, A., and Lippard, S. J. (1996) Biochemistry 35, 10004-10013.

55. Brabec, V., and Kasparkova, J. (2002) Drug Resist. Updates 5, $147-161$.

BI034933U 